\title{
JUDIKATŪRA UN TIESAS SPRIEŠANA
}

\section{CASE LAW AND ARBITRATION OF JUSTICE}

\author{
Mārcis Krūmiñš, $M g$. iur.
}

\section{Summary}

"Case law" designates a set of lessons arising from judgments of the court, from the opinions expressed by scientists and practitioners, which are incorporated and used in judicial judgments to justify it or other grounds of the court.

In many cases, the concept of case law is unduly narrowed, leading to misuse of the rule of law.

A more understandable development of the case law based on a comprehensive analysis of the issue will ensure a more similar understanding and application of the law, which, in turn, will boost public confidence in the court.

Atslēgvārdi: judikatūras jēdziens, tiesību normu piemērošana, atziņu kopums

Keywords: concept of case law, application of legal provisions, set of recognitions

\section{Ievads}

Raksta mērḳis ir apskatīt spriedumā ietvertās judikatūras robežas un tās atbilstību termina "judikatūra" izpratnei un piemērošanai praksē. Terminoloǵijas izpratne un piemērošana praksē ir viens no būtiskiem priekšnoteikumiem tiesu varas darbības stiprināšanā, efektivizēšanā un sabiedrības uzticības palielināšanā tiesām.

Tiesu darba efektivitāti un rezultātu, kas veicina patiesības noskaidrošanu katrā procesā, ietekmē ne tikai juridiskais pamats, proti, teorijas zināšana, tiesību normu izpratne un piemērošana, juridiskā kultūra, zināšanas un to piemērošana praksēe, bet arī sadarbība starp tiesu varas īstenotājiem - tiesnešiem un citām personām, kuras tieši vai netieši ir saistītas ar tiesu varu. Ne tikai tiesneši, bet arī tiesību zinātnieki un praktiḳi veic daudzo un dažādo spriedumu analīzi, pēta tiesību normu izskaidrošanas un piemērošanas procesus, kā arī izsaka viedokḷus vienā vai otrā virzienā. Teorētiskiem pètījumiem un skaidrojumiem ne vienmēr ir jāsakrīt ar konkrētā periodā pieṇemto tiesību normu skaidrojumiem un tā brīža izpratni, jo arī tiesību normu izpratne, laikam ritot, var mainīties. Izmaiņas notiek atbilstoši apgūtām un izanalizētām zināšanām un laikam.

Šajā rakstā autors izmantojis aprakstošo jeb genēzes metodi, kā arī salīidzinošo un sociologijas metodi, kas, pēc autora domām, salīdzinoši precīzi raksturo pašreizējo situāciju apskatāmajā jautājumā.

Raksta autors balstās uz priekšnoteikumu, ka judikatūra ir atziṇu kopums, kas veidojas, savstarpēji mijiedarbojoties tiesas spriedumos, kā arī zinātnieku un 
praktiķu izteiktajām atziṇām un tiek atspoguḷots tiesu nolēmumos. Tas izpaužas konkrētu tiesību normu interpretācijā un piepildīšanā ar noteiktu saturu. Ja tiek ievēroti visi elementi, tas dod sabiedrībai precīzāku un skaidrāku izpratni par tiesas varas reālo darbību, īstenojot praksē likumdevēja pieṇemtās tiesību normas.

Tiesām pieder tiesu vara, tomēr nedrīkstētu aizmirst, ka “.. nekontrolēta vara, kura nevienam nav atbildīga, agrāk vai vēlāk noved pie tirānijas. Savukārt atkarīgs varas atzars neveic pilnvērtīgi savas funkcijas". ${ }^{1}$ Tā nav seno filozofu, bet gan mūsu pašu kolēǵu atziṇa, kurai ir grūti nepiekrist. Tas gan ir teikts saistībā ar varas dalīšanas principu, taču, pēc autora domām un gūtajām atziṇām no citiem autoriem un pieejamās informācijas, to varētu teikt arī par tiesas nolēmumu analīzi, ko veic tiesneši, piemērojot konkrētās tiesību normas. Tiesas spriedums, kas stājies likumīgā spēkā, ir likums un ir jāpilda. Sprieduma kontrole ir tā analīze, kurā atspoguḷojas viena vai otra tiesas spriedumā ietvertā tiesību normas interpretācija.

Viena no tiesību normas interpretācijas pamatlietām ir tā, ka, sākot ar 2004. gada likumā iekḷautajiem grozījumiem, tiesību norma uzliek par pienākumu tā piemērotājiem ṇemt vērā judikatūru. ${ }^{2}$

\section{Jēdziena "judikatūra" izpratne}

Pēc jēdziena “judikatūra” iekḷaušanas Civilprocesa likumā salīdzinoši daudzi tiesību zinātnieki un praktiki vairāku gadu garumā sniedza savu skatījumu par šo jēdzienu. Pie jēdziena "judikatūra" skaidrošanas ik pa laikam nākas atgriezties, jo izpratne par to ir mainīga un visu laiku attīstās. Un tas ir apsveicami, jo tikai diskusijās izkristalizējas konkrētā jēdziena visaptverošais saturs. Viens no virzieniem, kas izkristalizējies tiesu praksē un ko uzsver arī Gundega Miķelsone 2015. gadā savā promocijas darbā - "judikatūra ir visas tiesiskās juridiski nozīmīgās atziṇas, kas ietvertas tiesu un tiesnešu (turpmāk arī - tiesa) nolēmumos un ko tiesa formulējusi, lietojot jebkuru juridisko metodi, jo îpaši tiesību normu interpretācijas un tiesību tālākveidošanas rezultāts". ${ }^{3}$ Uzsvars tiek likts uz tiesu spriedumiem, kuri ir publicēti, taču parādās viena būtiska iezīme - "visas juridiski nozīmīgās atziṇas", un tādas ir ne tikai tiesu nolēmumos. Tomēr autore šo virzienu neattīsta, akcents vienalga tiek likts uz tiesu nolēmumiem. Mazsvarīgs nav apstāklis, ka nolēmumos atsauces galvenokārt ir tieši uz Augstākās tiesas nolēmumiem. To uzsver Jānis Neimanis, balstoties uz vācu zinātnieku atzinumiem. ${ }^{4}$ Iepazisstoties ar šo jautājumu sīkāk, ir redzams, ka arī Latvijas Republikas Augstākā tiesa savā tīmekḷvietnē ievietojusi konferences materiālu, kur asociētā profesore Daiga Rezevska atzīmē:

1 Osipova S., Strupišs A., Rieba A. Tiesu varas neatkarības un efektivitātes palielināšanas un nostiprināšanas rezerves. Jurista Vārds, 09.03.2010., Nr. 10 (605). Pieejams: https://www.juristavards.lv/doc/206150-tiesuvaras-neatkaribas-un-efektivitates-palielinasanas-un-nostiprinasanas-rezerves/

2 Grozījumi Civilprocesa likumā: LV likums. 5. panta 6. daḷa. Latvijas Vēstnesis, 23.04.2004., Nr. 64. Pieejams: https://likumi.lv/doc.php?id=50500

3 Miķelsone G. Judikatūras nozīme Latvijas kā demokrātiskas tiesiskas valsts tiesiskajā sistēmā. Promocijas darbs. Rīga: LU, 2015, 41. lpp. Pieejams: https://kopkatalogs.lv/F/PELQBDFISTUQ9FG96P4YBTTBAHGAYENX6L2GPV8K5GJM2FJ3A9-02195? func=find-b\&request=Gundega + Mi\%C4\%B7elsone\& find_code $=$ WAU \&adjacent $=N \& x=0 \& y=0 \&$ filter_code_2=WYR\&filter_request_2 =\&filter_ code_3=WYR\&filter_request_3=\&filter_code_4=WDD\&filter_request_4=

4 Neimanis J. Ievads tiesībās. Rīga: autora izdevums, 2004, 71. lpp., atsauce uz: Ruthers B. Rechtstheorie. Munchen: Beck, 1999, R. 235. 
"Judikatūra (gan vispārējās jurisdikcijas tiesu, gan EST, ECT, ST) ir tiesību avots jebkurā Latvijas tiesiskās sistēmas tiesību nozarē, neatkarīgi no tā, vai likumdevējs ir spējis to pienācīgi noformulēt rakstītajā normatìvajā aktā vai nē, jo tiesību avots demokrātiskā tiesiskā valstī ir nevis likumdevējs, bet gan suverēns." ${ }^{5}$

Minētais virziens ir tā sauktā ideālā situācija, kad visi judikatūrā minētie nolēmumi ir bez kḷūdām un atziṇas atbilst tiesību normā paredzētam jēgumam vai izpratnei, kā arī tiesību teorijas pamatiem un tiesību zinātnieku paustajām teorētiskajām atziņām. Tomēr nevienam nav noslēpums, ka bez teorētiskajām zināšanām un teorētisko atziṇu precīzas piemērošanas praksē nav iespējams taisìt nolēmumus, kas atbilstu likumā noteiktajām prasībām un tiesību normās ietvertajiem pamatprincipiem.

Apskatītais virziens judikatūru uztver kā tiesu (galvenokārt augstāko tiesu) nolēmumos konstatētās atziṇas, un tas vērsts tikai uz tiesas spriedumiem. Pēc autora domām, minētais skatījums ir nepilnīgs un, piemērojot tiesību normas praksē (spriedumos), var radìt kḷūmīgas situācijas tiesību normas piemērošanas procesā. Kā rāda prakse, tas ne tikai var radīt, bet arī rada situācijas, kad tiesas spriedumos kā pamatojums tiek minēti tiesu nolēmumi, kuri ir kḷūdaini. Šādi nolēmumi nebūtu uztverami kā "judikatūra” un iekḷaujami daḷā, ko saskaṇā ar Civilprocesa likuma 5. panta 6. dalı saprotam ar jēdzienu “judikatūra”, un tas savukārt uzliktu par pienākumu citiem tiesnešiem tos ievērot un izmantot tiesu taisītajos nolēmumos.

Ir zināms, ka likums ir likums un tas ir jāpilda visiem, kaut arī tas nav pareizs. Ja nav pareizs, tad likums ir jāmaina, taču nevienam nav dotas tiesības likumu neievērot, it īpaši tiesnešiem, skatot lietu!

Vai šajā gadījumā maināms likums attiecībā uz jēdzienu “judikatūra”? Atbilde ir vienkārša - nē! Tikko minētais ir tieši saistīts ar praksi. Tiesību normu piemērošanu, veicot tās vai citas darbības un pieņemot vienu vai otru nolēmumu, veic tiesa.

Lai praksē samazinātu to gadījumu skaitu, kad kḷūdaini spriedumi tiek izmantoti, izskatot līdzìgas lietas, jo tā paredz likums, autors uzskata, ka judikatūras jēdziens ir saprotams plašāk nekā tikai tiesu nolēmumos fiksēti konstatējumi un pamatojumi. Protams, tie ir ņemami vērā, atsaucoties uz judikatūras analīzi kādā no tiesu nolēmumiem, taču citā spriedumā minètā atziṇa nedrīkstētu būt vienīgais arguments nolēmumu motivēšanai vienā vai otrā virzienā. Var tikai piekrist profesora Kalvja Torgāna rakstītajam: "Reiz norādītam argumentam var būt pietiekoša nozīme tiesību izpratnē. Tādēl noškirt judikatūru no tiesu prakses nevar pēc nolēmumu pareizuma. Nošķiršana notiek citādi: no prakses materiāliem nodala abstrakto atziṇu kopas."' Sprieduma motīvu daḷā būtu vēlams norādìt konkrēto atziṇu par tiesību normas iztulkošanu, piemērojot teorētisko skaidrojumu, un tikai papildus būtu norādāma atsauce uz konkrēto tiesību normu. Kad minētā tiesību norma ir guvusi savu teorētisko skaidrojumu, tad, protams, tā kā tas minēts Latvijas Republikas Satversmes tiesas spriedumos un arī Eiropas Savienības Tiesas spriedumos, kuros liktas atsauces uz "judikatūru” vai iepriekšējos spriedumos pausto, varētu likt tikai atsauces uz konkrēto spriedumu. Būtiskākais ir tas, ka spriedumā, uz kuru atsaucas, ir jābūt precīzam, visaptverošam piemērojamās tiesību normas skaidrojumam. Arī pētījumā, ko veica tiesību zinātnieki un praktiķi,

\footnotetext{
5 Rezevska D. Judikatūra kā tiesību avots: izpratne un pielietošana, secinājums. Latvijas Republikas Augstākā tiesa. 2010. Pieejams: http://at.gov.lv/files/uploads/files/docs/conferences/rezevska.ppt

6 Torgāns K. Judikatūras teorija un pielietojamā judikatūra. Jurista Vārds, 13.12.2005., Nr. 47.
} 
konstatēts, ka “.. judikatūra nerodas valsts veiktas atlases kārtībā, bet gan brīvas juridiskās domas attīstības gaitā”. 7 Autors uzskata un pieṇem, ka pašlaik nepastāv strīds par to, ka juridisko domu attīsta un veido tiesību zinātnieku, tiesību normu piemērotāju un izmantotāju savstarpēja mijiedarbība un tie nav tikai tiesneši.

Tiesas spriedumi ir konkrēti un rezolutīvā daḷā vērsti uz konkrētām personām. Savukārt sprieduma motīvu daḷas tiek izmantotas citos spiedumos, ja tāda nepieciešamība rodas. Tieši spriedumu motīvu daḷās, analizējot un vērtējot lietā iesniegtos pierādījumus, būtu nepieciešams vairāk spriedumu balstīt uz nodalītajām abstrakto atziṇu kopām. Kur tad šìs abstraktās atziṇas meklēt, ja tās nav spriedumos? Tās veidojas tiesību zinātnieku izanalizētajos, aprakstītajos un izteiktajos vērtējumos un domās. Egils Levits rakstā par tiesiskās vienlīdzības principu atzìme $\bar{e}^{8}$ un uzsver, ka tiesu prakses jēdziens nav viens un tas pats, kas "judikatūra". 9

\section{Judikatūras praktiskie aspekti}

Rakstot par judikatūru, nav iespējams iztikt bez piemēriem. Latīnu valodas vārds iudicare tiek lietots vairākās nozīmēs. Skaidrojošā vārdnīcā varam atrast šādus skaidrojumus: 'tiesāt, uzskatīt, izlemt, vērtēt, domāt, novērtēt'. ${ }^{10}$ Tas norāda, ka jēdziens "judikatūra” sevī var ietvert dažādus aspektus, galvenais, lai mēs paši būtu gatavi to pieņemt un izmantot.

Judikatūrai pastāv vairākas savstarpēji saistītas šķautnes, kas izvērtējamas visos gadijumos kā viens vesels, jo, izcel̦ot vai aplūkojot tikai vienu aspektu, rezultātā var nonākt pie kḷūdaina vai nekorekta secinājuma.

Lai nerastos pārpratumi, citāts ir apjomīgs. Konkrētā sprieduma motīvu daḷā ir rakstīts:

“[8.2] Tiesību doktrīnā skaidrots, ka atkarībā no defekta rakstura juridiskā aktā civiltiesības kādu aktu atzīst par nederīgu, tas ir, par spēkā neesošu tieši uz likuma pamata (ipso jure) vai par atceḷamu, kurā ir nepieciešama ieinteresētās personas darbība - apstrīdēšana. Akta nederīgums iestājas tieši - pats no sevis, piemēram, rīcībnespējīgas personas noslēgts akts. Tiesai pašai jāatzīst akts par spēkā neesošu, kaut arī ieinteresētās personas to neapstrīdētu. Turpretī atcel̦amības sankcija neiestājas pati no sevis, bet tikai uz tiesas sprieduma pamata. Atcel̦ot aktu jāatzīst, ka tas nemaz nav bijis. Līdz tiesas spriedumam tāds akts ir spēkā (sk. K. Čakste. Civiltiesības. - Rīga, 1937, 27.-28. Ipp., K. Čakste. Civiltiesības. Lekcijas. Raksti. - Rīga: Apgāds Zvaigzne ABC, 2011, 60.-61. lpp.).

Līdzīgu viedokli par jautājumu, kad tiesa, neesot pretprasībai par darījuma atzīšanu par spēkā neesošu, îr tiesīga izvērtēt lietas dalībnieka ierunās izteiktos argumentus par darījuma tiesiskumu, paudis arī Latvijas Senāts. Tā, 1933. gada 22. novembra nolēmumā lietā Nr. 37 Senāts norādījis, ka "Pēc Tiesu palātas pareiza aizrādījuma, atbildētājam bija tiesība uz darījuma fiktīvo raksturu atsaukties

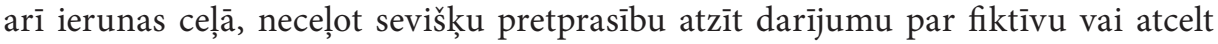

\footnotetext{
7 Osipova S., Strupišs A., Rieba A. 2010.

${ }^{8}$ Levits E. Par tiesiskās vienlīdzības principu. Latvijas Vēstnesis, 08.05.2003., Nr. 68.

${ }^{9}$ Latīṇu valodas vārds iudicare - 'tiesāt, uzskatīt, izlemt, vērtēt domāt novērtēt'. Glosbe - daudzvalodu tiešsaistes vārdnīca, latīnu - latviešu vārdnīca. 2019. Pieejams: https://lv.glosbe.com/la/lv/iudicare

${ }^{10}$ Glosbe - daudzvalodu tiešsaistes vārdnīca, latīṇu - latviešu vārdnīca. 2019. Pieejams: https://lv.glosbe. com/la/lv/iudicare
} 
darījumu. [..] Tiesu palātas konstatējums par darījuma fiktīvo raksturu vien jau deva Tiesu palātai pietiekošu pamatu pārņemšanas darījumu atzìt par nederīgu pēc CL (Latvijas (Baltijas) privātlikuma) 2951., 2922. p.”. Lìdzīga atziṇa izteikta Senāta 1938. gada 14. decembra nolēmumā lietā Nr. 43 (sk. Latvijas Senāta spriedumi (1918.-1940.), 12. sējums, Senāta Civilās kasācijas departamenta spriedumi. Rìga: Latvijas Republikas Augstākā tiesa, Senatora Augusta Lēbera fonds, 1998, 4906.-4907. lpp., XV. Izvilkumi no Latvijas Senāta Civilā kasācijas departamenta spriedumiem. Sastādījuši senators F. Konradi un Tiesu palātas loceklis A. Valters. Tieslietu ministrijas Vēstneša pielikums, 1939, 42.-43. lpp.)."11

Jāatzīmē, ka minētais spriedums ir pieejams Latvijas Republikas Augstākās tiesas judikatūras sadal̦ā.

Iepazīstoties ar šo spriedumu un analizējot to saistībā ar teorētiskiem jautājumiem, rodas pamatots jautājums - vai, izmantojot materiālo tiesību normu skaidrojumu, drīkst pamatot un vai saskaņā ar spēkā esošo doktrīnu tiesa drīkst grozīt Civilprocesa likuma normās noteikto kārtību?

Lasītāju uzmanību vēlētos vērst tieši uz pirmajā citētajā rindkopā minēto teikumu: "Tiesai pašai jāatzīst akts par spēkā neesošu, kaut arī ieinteresētās personas to neapstrīdētu." Tiesa procesuālo rīcību pamato ar materiālajām tiesību normām. Protams, tiesneši, tai skaitā Augstākās tiesas tiesneši, ir pakḷauti tikai likumam, taču tiesas sprieduma lasītājs vēlas saprast, kas bijis pamatā šādai civilprocesuālās tiesību normas interpretācijai, pamatojot procesuālo tiesību ar materiālajām tiesību normām. Šādu atbildi diemžēl spriedumā izlasìt neizdevās. Civilprocesa likuma 74. panta trešās daḷas 3. punkts noteic, ka prasītājs ir tiesīgs “.. rakstveidā grozīt prasības pamatu vai priekšmetu vai palielināt prasījumu apmēru, iekams nav uzsākta lietas izskatīšana pēc būtības" (Civilprocesa likuma 163. pants). Tas attiecas uz pirmās instances tiesu. Judikatūras sadaḷā bez jebkādiem papildu paskaidrojumiem ir iekḷauts spriedums, kura motīvu daḷā Augstākā tiesa rīkojas pretēji Civilprocesa likumā noteiktajām normām. Pašreiz spēkā esošā tiesību doktrīna noteic, ka tikai prasītājam, sniedzot un uzturot prasības pieteikumu, vai atbildētājam, iesniedzot pretprasību un to uzturot līdz lietas sākšanai to skatīt pēc būtības, ir tiesības grozīt prasības priekšmetu vai pamatu. Likums tiesai šādas tiesības nepiešķir. Iespējams, tas ir maināms un tādas tiesības var tikt dotas tiesai, taču tad ir vajadzīgs likumisks pamats, lai ikvienā lietā, kurā pastāv līdzìgi apstākḷi, jebkuras instances tiesnesis varētu veikt noteikta rakstura darbības. Iespējams, ka arī apskatītajā piemērā tiesas rīcība ir pamatota, tomēr, iekḷaujot šo spriedumu sadaḷā “judikatūra”, būtu tikai saprotami, ja tiesa sprieduma motīvu daḷā būtu sniegusi skaidrojumu un pamatojumu. Konkrētajā spriedumā tiesa nav sniegusi skaidrojumu un pamatojumu, uz kādu tiesību normu vai tiesību principu pamata tā rīkojas pretēji Civilprocesa likumā noteiktajām tiesību normām. Nav dots skaidrojums arī par to, kāpēc materiālajām tiesību normām dodama priekšroka attiecībā pret procesuālajām tiesību normām, izlemjot procesuālas dabas jautājumu. Iespējams, tā var rīkoties, tomēr, ievērojot to, ka Latvijas Republikas Augstākā tiesa ir augstākā tiesu instance valstī, kas nosaka rīcības modeli tiesnešiem un tiem, kuri vēršas tiesu instancēs, būtu tikai log̣iski, ja spriedumos, kuri tiek iekḷauti judikatūras sadaḷā, būtu atrodami skaidrojumi tiesas norādījumiem, kā

11 Latvijas Republikas Augstākās tiesas Civillietu departamenta 26.05.2017. spriedums lietā Nr. C30614710, SKC-166/2017. 
turpmāk piemērojama tā vai cita tiesību norma, ieskaitot arī Civilprocesa likumā rakstītās tiesību normas.

Minētā sprieduma [9] punktā tiesa konstatē, ka Civillietu tiesas kolēgija konkrētajā gadījumā nav izpildījusi tiesas spriešanas pamatuzdevumu - atrast taisnīgāko un lietderīgāko strīda risinājumu. Tas ir saprotami. Tomēr rodas jautājums ja ievērojam sprieduma 8.2. daḷā rakstīto, tad kā ir ar likumības principu? Kā zinām, tad process ir formālo lietu vešanas kārtība un ikvienam lietas dalïbniekam ir tiesības paļauties, ka tiesa ievēros likumā noteikto kārtību. Autoram skaidrojumu minētajā jautājumā spriedumā neizdevās atrast.

Otra lieta, kas autoram izraisīja pārdomas par judikatūras jautājuma būtisko nozīmi un procesuālā likuma piemērošanu līdzīga rakstura lietās, ir saistīta ar ierobežotas pieejamības spriedumu, ${ }^{12}$ kas tāpat kā iepriekš minētais ir iekḷauts Augstākās tiesas tīmekḷvietnes sadaḷā "Judikatūra". Tā kā lietai noteikts slēgtas lietas statuss, autors var izmantot tikai publicētos izvilkumus no sprieduma.

Civillikuma ${ }^{13}$ 89. pants noteic: "Katrs laulātais patur mantu, kas piederējusi viņam pirms laulības, tāpat arī to mantu, ko viņš iegūst laulības laikā kā atsevišķ̣u mantu.

Viss, ko laulības laikā laulātie iegūst kopīgi vai viens no viniem, bet ar abu laulāto lìdzekliem vai ar otra laulātā darbības palīdzību, ir abu laulāto kopīga manta; šaubu gadījumā jāpien,em, ka šì manta pieder abiem lìdzīgās daḷās [autora izcēlums].

Ja kādas vienam laulātajam piederošas mantiskas vērtības laulības laikā atvieto ar citām, pēdējās ir šā laulātā manta.”

Minētā sprieduma motīvu daḷas 11. punktā rakstīts: “.. Laulāto kopīgas mantas dalǐšanas lietās galvenā nozīme ir tiesas sniegtajam apstākḷu vērtējumam un argumentācijai, tāpēc ir ḷoti svarīgi, lai spriedumi būtu labi motivēti, no kuriem ir saprotama tiesas pozīcija, kāpēc laulāto kopīgā manta tiek sadalīta tieši tā un nevis citādi." Pamatots un precīzs konstatējums, kas ir saprotams ikvienam un kas atbilst procesuālajām tiesību normām, kuras tiek izvirzītas tiesas spriedumam saskaṇā ar likumu un vispārīgiem tiesību principiem.

Apskatāmā sprieduma motīvu 12. daḷā norādīts, ka saskaṇā ar materiālajām tiesību normām, ja nekustamais īpašums ir iegādāts laulības laikā, tad atbilstoši Civillikuma 89. pantam un 91. pantam tas var būt gan viena laulātā atsevišķa manta, gan arī laulāto kopīga manta atkarībā no tā iegūšanas veida un tajā izmantotajiem finanšu līdzekḷiem. Turpat atzīmēts, ka tiek ņemts vērā laulības laikā iegūtā strīdus nekustamā īpašuma iegūšanas veids - kurš no laulātajiem ir iegādājies vai ieguvis strīdus nekustamo īpašumu, vai nekustamo īpašumu ir iegādājušies abi laulātie kopīgi, vai arī viens no laulātajiem ir devis otram laulātajam līdzekḷus nekustamā īpašuma iegādei vai kā citādi ar savu darbību ir veicinājis un sekmējis nekustamā īpašuma iegādi. Tāpat spriedumā ir teikts, ka vērtējams ir jautājums, kādā veidā ir izpaudusies otra laulātā dalība nekustamā ìpašuma iegādē un kādus pierādījumus laulātais ir iesniedzis tiesā savu prasijumu pamatošanai [autora izcēlums]. Te rodas jautājums, vai tiešām ir vērtējami tikai un vienīgi materiālie ieguldījumi. Pēc autora domām, tas neatbilst ne materiālajām, ne arī

${ }^{12}$ Latvijas Republikas Augstākās tiesas Civillietu departamenta 2018. gada [..] spriedums lietā Nr. [..] SKC[c]/2018.

${ }^{13}$ Civillikums: LV likums. Valdības Vēstnesis, 20.02.1937., Nr. 41. Pieejams: https://likumi.lv/doc.php? id $=225418$ 
procesuālajām tiesību normām. Materiālajās tiesību normās ir dota alternatīva abu laulāto lìdzekḷi vai otra laulātā palīdzīgas darbības. Tajā pašā laikā attiecībā uz procesuālajām tiesībām tiesa "laulātā palīdzību“ ir ierobežojusi ar "otra laulātā dalību nekustamā ìpašuma iegādē un kādi pierādījumi tam iesniegti”. No sprieduma rodas iespaids, ka tiek uzsvērta tikai un vienīgi materiālā puse. Tā nedrīkstētu būt. Saskaṇā ar likumu, pēc autora domām, būtiska ir nevis tikai materiālā līdzdalība, bet gan jebkāda laulātā palīdzība - bērnu radīšana, bērnu auklēšana un pieskatǐšana, kamēr otrs laulātais vairo g̛imenes labklājību; jebkādas darbības, kas veicina otra laulātā darbaspējas un nodošanos ǵimenes materiālās labklājības celšanai. Pamatota prasība, kas noteikta likumā, ir pierādījumu iesniegšana par iepriekš minētajām darbībām. Otra laulātā dalība nekustamā īpašuma iegādē ir saprotama visplašākajā izpratnē, un tas nedrīkstētu aprobežoties tikai un vienīgi ar materiālajām vērībām. Pēc autora domām, tas būtu uzsverams un aprakstāms daudz precīzāk un skaidrāk arī tiesu spriedumos, kuri tiek ievietoti judikatūras sadaḷā.

Intervijās respondenti norādija, ka neesot pietiekami detalizēti noteikta tiesnešu amata kandidātu stažěšanās kārtība, kas radot problēmas salīdzināt stažieru kvalifikāciju. Turklāt stažiera vadīšana prasa pietiekami daudz laika no vadìtāja, un tas reizēm traucē, it īpaši personāla trūkuma un pārslodzes apstākḷos.

\section{Kopsavilkums}

1. Judikatūra ir atziṇu kopums, kas veidojas no tiesas spriedumiem, kā arī zinātnieku un praktiķu izteiktām atziṇām, kas tiek iekḷautas un izmantotas tiesu nolēmumos, lai pamatotu to vai citu tiesas spriedumu.

2. Daudzos gadijumos nepamatoti tiek sašaurināts judikatūras jēdziens, un tas noved pie nepareizas tiesību normas izmantošanas.

3. Judikatūras saprotamāka veidošana, kas balstīta uz vispusīgi izanalizētu jautājumu, nodrošinās līdzīgāku tiesību normu izpratni un piemērošanu, bet tas savukārt veicinās sabiedrības uzticību tiesai. 